\title{
REVENDO O INDIANISMO BRASILEIRO: A LÁGRIMA DE UM CAETÉ, DE NÍSIA FLORESTA ${ }^{1}$
}

Constância Lima Duarte Universidade Federal de Minas Gerais

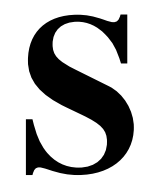

e procuramos o nome de Nísia Floresta nas antologias mais conhecidas da Literatura Brasileira ou em livros que tratam da história literária nacional do século XIX, com certeza não vamos encontrá-lo. Raros foram os críticos e historiadores que dele tiveram notícia e mais raros ainda os que a citaram em meio aos ilustres nomes masculinos de nossas letras.

Não é o caso aqui, naturalmente, de se questionar os critérios de seleção de autores e textos nas antologias, nem de apontar posições contrárias à participação feminina nas artes e na vida política e social do país de então. Sabemos que bem poucas foram as mulheres que ousaram ultrapassar tais barreiras publicando obras durante o século XIX e, mais ainda, em suas primeiras décadas. E Nísia Floresta foi uma destas. A história de sua vida é pontilhada de inúmeros exemplos de ruptura com os padrões de comportamento vigentes e os livros que escreveu atestam, de forma definitiva, sua participação nas letras nacionais.

Romântica, indianista, abolicionista, feminista, republicana e ensaísta das mais atuantes, Nísia nasceu na pequena província de Papary (RN) em 1810, permanecendo aí apenas até a adolescência. Depois, casada, e logo separada do marido, mudou-se para

\footnotetext{
${ }^{1}$ Este texto é parte de um estudo sobre a autora, e encontra-se mais completo em Nisia Floresta: vida e obra. Natal: UFRN, 1995.
} 
Pernambuco e nos anos seguintes residiu em Porto Alegre e no Rio de Janeiro, onde dirigiu um colégio feminino durante alguns anos. Mesmo a corte deve ter-lhe parecido acanhada, pois em 1849 seu nome se encontra na relação dos passageiros da galera francesa Ville de Paris, com destino ao Havre. Durante quase trinta anos de sua vida (voltando apenas duas vezes ao Brasil), ela viajou por diversos países e relacionou-se com a intelectualidade européia, residindo ora em Paris, ora em Roma ou Florença e, por fim, em Rouen, onde faleceu em 1885.

Entre os diversos livros que Nísia Floresta escreveu, um se destaca por se inserir de forma especial no contexto romântico indianista. Trata-se do poema A lágrima de um Caeté ${ }^{2}$, publicado no Rio de Janeiro em 1849, sob o pseudônimo de Telesila. Aliás, no Jornal do Comércio de 25 de maio deste ano, encontra-se um anúncio acerca deste livro, nos seguintes termos: "Reimprimiu-se este interessantíssimo poema; vende-se na Typographia da rua S.José 45, e nas lojas do costume." Estas e outras informações levaram Adauto da Câmara a acreditar que desta obra foram tiradas pelo menos duas edições no mesmo ano de 1849 , em maio e em junho ${ }^{3}$, com o que concordamos plenamente.

O motivo de tal sucesso é fácil explicar: com certeza deveuse ao fato de o poema tratar também da Revolução Praieira, um assunto palpitante entre os liberais. A Revolução acabava de ser decidida em fevereiro, em Pernambuco, com a derrota das forças revoltosas e a morte de Nunes Machado, e, por causa disto, alguns críticos se referiram ao livro como uma "poesia sobre a Revolução Praieira", privilegiando este aspecto em detrimento da questão indígena. Este equívoco gerou outro: fez com que vários autores considerassem A lágrima de um Caeté e Poesias da Revolução Praieira como sendo dois títulos distintos.

${ }^{2}$ Todas as citações são da seguinte edição: A lágrima de um Caeté. Natal: Fundação José Augusto, 1997.

3 CÂMARA, 1938. 
Uma das boas surpresas que tive enquanto pesquisava Nísia Floresta foi a descoberta em Florença de uma edição italiana de 1860 - Le lagrime d' un Caeté - até então completamente ignorada. Quem assina a tradução é Ettore Marcucci, um escritor florentino que aparece citado com a esposa, a poetisa Clorinda Marcucci, em Trois Ans en Italie, livro escrito por Nísia Floresta sobre o período em que residiu na Itália. No Prefácio ele se dirige ao filho de Nísia, Augusto Américo de Faria Rocha, a quem dedica o trabalho e explica os motivos que o levaram a traduzir o poema.

A respeito do modo que eu encontrei para testemunhar-vos o meu ânimo, e cativar o vosso, não poderia ter escolhido coisa melhor para vos apresentar do que uma minha traduçãozinha do português para uma das mais melodiosas línguas vivas, por vós predileta e muitíssimo bem dominada, mas que agradar-vos-á sobretudo porque obra brasileira, da própria mão daquela vossa mãe que tanto adorais, e entre suas composições aquela por vós mais prezada. Tornando italiano este poemeto, sorriu-me, ademais, a esperança de oferecer aos meus nacionais uma leitura de saudável repasto para os livres e magnânimos sentimentos que respondem bem àqueles professados hoje na Itália. ${ }^{4}$

Os elogios de Ettore Marcucci - um escritor respeitado por seus contemporâneos - provavelmente devem ter contribuído para a divulgação deste texto junto ao público italiano. E, talvez (quem sabe?), tenha sido este o único livro brasileiro daquela época a ser traduzido e publicado neste país.

No Brasil, apenas em 1938 iria sair a terceira edição, oitenta e nove anos após as anteriores. A iniciativa foi da Revista das Academias de Letras e trazia uma Introdução de Modesto de Abreu, com Notas de Adauto da Câmara..$^{5}$ Infelizmente, esta edição não se preocupou em seguir as disposições originais das estrofes e contém erros tipográficos tão sérios que comprometem até a compreensão de alguns versos. Além disso, veicula opiniões pouco elogiosas à autora e ao poema, pois tanto Adauto da Câmara como Modesto de

${ }^{4}$ MARCUCCI, 1860.

5 CÂMARA, 1938. 
Abreu consideraram A lágrima de um Caeté um texto menor na obra nisiana, apesar da repercussão que o livro teve em sua época e dos aspectos inovadores que contém. Segundo Adauto, nas Notas desta edição, trata-se de "uma obra medíocre, muito inferior às que a insígne escritora produziria depois"; e na Introdução, de Modesto de Abreu, o autor afirma que "o alto merecimento intelectual de Nísia Floresta Brasileira Augusta não pode ser hoje aferido através de sua produção poética..."

Tal julgamento na hora em que o texto era redescoberto, mais a identificação de seu tema como sendo o da "Revolução Praieira", um movimento político contrário aos interesses imperiais e aos conservadores em geral (caso em que Adauto e Modesto podem ser incluídos), deve ter contribuído muito para que A lágrima de um Caeté fosse novamente esquecida. Estas críticas devem ter fornecido, inclusive, argumentos para o pré-juízo de outros autores que, de antemão, deixavam o poema de lado ao arrolar e estudar textos voltados para o índio brasileiro.

Tudo isso ocorre porque o poema, em síntese, contém a conjunção de dois dramas: o do índio brasileiro espoliado pelo colonizador português; e o vivido pelos liberais durante a Revolução Praieira, acontecida em Pernambuco, de novembro de 1848 a fevereiro de 1849. Aparentemente distintos, estes dramas se entrelaçam à medida que o poema se desenvolve, até sua quase identificação. Como isso ocorre e como a poetisa tece esta trama é o que examino a seguir. Antes, porém, tornam-se necessárias algumas considerações sobre as palavras que a autora antepôs ao poema e ao episódio histórico da Revolução Praieira.

\section{O Avant-propos, a censura imperial e a Revolta Praieira}

Logo no início de A lágrima de um Caeté, o leitor encontra um lacônico Avant-propos em que a autora refere-se às dificuldades de impressão que seu livro teve na Corte e insinua a censura que sofreu, nestes termos: 
O infeliz Caeté, apesar de ter chegado a esta corte no mês de Fevereiro, logo depois da revolta dos Rebeldes em Pernambuco, é somente agora que lhe permitiram aparecer, e isto depois de o terem feito passar aqui por mil torturas inquisitoriais!... Graças à benfazeja mão, que o fez renascer, qual Fênix, das cinzas a que o haviam ou queriam reduzir! (p.35)

Apesar do tom algo misterioso, algumas informações preciosas aparecem nestas palavras. Fica-se sabendo que o poema foi escrito ao calor da hora, imediatamente após a morte de Nunes Machado que ocorreu no dia 2 de fevereiro de 1849. No mesmo mês ela já o queria impresso, mas devido a dificuldades que não especifica, só em maio saiu a primeira edição.

Quanto às "mil torturas inquisitoriais", que mais podem ter sido senão a censura imposta ao texto? Quando o lemos e percebemos a paixão com que o poema foi escrito, podemos imaginar como devem ter incomodado as idéias aí contidas, das quais cito, por exemplo, as acusações que faz aos desmandos autoritários dos governantes. O passado histórico pernambucano é tomado como pretexto para tratar do momento presente, para criticar a dominação colonial no país e revelar o extermínio dos primeiros habitantes do Estado. Além de violentas críticas aos portugueses, identificados sempre com os opressores, o texto exalta os movimentos revolucionários que surgiram durante o Império incitando a novas rebeliões, o que por si só já "justificaria” a censura.

E, à medida que se lê o poema de Nísia Floresta, mais evidentes se tornam algumas lacunas que se interpõem ou entre uma estrofe e outra, ou entre versos da mesma estrofe. Estas lacunas, representadas por linhas pontilhadas e em número de oito, longe de constituírem recurso estilístico da época, parece que nos indicam a ausência de verso(s) e, quem sabe, até mesmo de estrofe(s). Se não chegam a comprometer a compreensão do texto como um todo, em vários momentos estas linhas deixam em suspenso uma idéia ou uma fala, cuja continuidade não encontramos. O mistério permanece na "benfazeja mão que o fez renascer". Cabe a pergunta: quem terá sido o responsável por sua liberação e impressão? Provavelmente não o 
saberemos nunca, a não ser que foi poderoso o bastante para fazer este poema ressurgir "das cinzas a que o haviam ou queriam reduzir".

O episódio dos revoltosos da Praieira, por exemplo, surge mais ou menos de repente no poema. Aliás, é precisamente aí que se percebe mais nitidamente a ausência de alguns versos. Se permanecia alguma dúvida a respeito de o texto não ter sofrido censura, nesta passagem as dúvidas diminuem. E, se se considera ainda a época em que o poema foi escrito e publicado, a intenção explícita de se exaltar Nunes Machado e a condenação dos repressores, aliada ao incentivo de outras revoltas e novos heróis, compreende-se a dificuldade de publicação denunciada pela autora e a imposição da censura pelos conservadores.

A revolta havia estourado em novembro de 1848 e em janeiro Nunes Machado assinava com os demais líderes - Pedro Ivo e Antônio Borges da Fonseca - um Manifesto ao Mundo que obteve repercussão por todo o país. (Pedro Ivo, aliás, também mereceu um poema-homenagem de Castro Alves). A corte acompanhava entre surpreendida e alarmada, a crescente força do movimento que rapidamente recebia a adesão popular, o apoio dos liberais e teimava em resistir às tropas do Imperador, para lá deslocadas. A audácia do Manifesto de $1^{\circ}$ de janeiro de 1849 pregando o voto livre e universal, a plena liberdade de expressão e da imprensa, a garantia de trabalho para todos e a extinção do Estado, entre outros pontos, revelava o nível de informação de seus líderes e a influência das mais avançadas teorias socialistas européias da época no movimento revolucionário. Segundo o historiador Amaro Quintas,

Idéias de reforma social, umas, inteiramente impregnadas de socialismo utópico, outras avançadas para o tempo, de verdadeiro socialismo quase científico, se infiltravam no meio pernambucano, deixando um lastro de reivindicações sociais que iria, encontrando pleno apoio nas aspirações ainda imprecisas da massa, agitar fortemente a Província. ${ }^{6}$

${ }^{6}$ QUINTAS, 1982. p. 40. 
Da perspectiva do poder central, era preciso sufocar esta rebelião o mais rápido possível e calar seus chefes, antes que tais idéias se alastrassem pelo país, pois a ideologia liberal ameaçava deixar de ser "o programa de um partido para se transformar na própria maneira de ser da vida social."” E, minimizada por alguns historiadores como tendo sido ora apenas uma "insurreição", ora um "simples conflito" entre partidos, a Praieira na realidade foi um dos períodos mais sangrentos da história pernambucana no século XIX, com 815 mortos e 1701 feridos, alcançando as dimensões de um "movimento social", provocado, por sua vez, pelo "estado de desequilíbrio econômico-social" no meio da massa. ${ }^{8}$

Nísia Floresta, apesar de nascida no Rio Grande do Norte, sentiase pernambucana como chegou a afirmar mais de uma vez em sua correspondência e seus ensaios. Conheceu de perto os principais líderes da rebelião - principalmente Nunes Machado-e partilhava com eles dos ideais de liberdade, defendendo também uma maior participação dos brasileiros na economia do país, então dominada pelos portugueses. Em sua militância literária, a autora mostrar-se-á sempre coerente com os princípios liberais, assumindo o discurso progressista em defesa do oprimido, seja ele o índio, o negro ou a mulher.

Após tais informações e digressões, destinadas a melhor contextualizar este poema, vejamos como A lágrima de um Caeté se constrói, isto é, como os elementos indianistas e de reformismo social estão aí trabalhados e em que o poema se diferencia ou se aproxima dos demais textos, seus contemporâneos.

\section{A lágrima de um Caeté}

Publicado logo após os Primeiros e Segundos cantos de Gonçalves Dias, este poema reúne as duas maiores tendências do romantismo brasileiro: a questão indígena e as lutas político-sociais,

\footnotetext{
${ }^{7}$ MARTINS, 1977. p. 399.

${ }^{8}$ QUINTAS, 1982. p. 30.
} 
ambas impregnadas de forte carga nacionalista. Para realizar esta fusão, a narrativa constrói dois tempos históricos: o da colonização e o do Império. No primeiro, o protagonista é o Caeté (representando o índio brasileiro), e o opressor, o colonizador português. No segundo momento, os protagonistas são os liberais (com destaque para Nunes Machado) e os antagonistas, os homens do Imperador. Na trajetória do tempo passado para o presente perpassa o drama do índio brasileiro: de protagonista da história a espectador da derrota liberal e da sua própria enquanto civilização. Assim, A lágrima de um Caeté se configura num lamento tanto pela derrota do indígena, quanto pela dos revoltosos de Pernambuco. A perspectiva é a mesma: é sempre a do vencido e oprimido pela força dos dominantes.

O texto paga tributo à herança clássica, através da presença de elementos formais retirados da tradição épica. Em sua dimensão atual possui 712 versos e, se não alcança o porte de uma epopéia, é, ainda assim, longo o suficiente para permitir a narração do drama histórico a que se propõe. Ao tematizar a derrota do índio, ligando-a ao fracasso dos liberais pernambucanos, o poema termina por assumir um indisfarçável tom de elegia que, aliás, o título já prenunciava.

A metrificação empregada é segura: às estrofes decassílabas, seguem-se outras em versos ora heptassílabos, ora hendecassílabos, ou ainda em redondilha menor. O "tom guerreiro" de Gonçalves Dias por vezes se encontra também aqui, num evidente diálogo desta autora com o poeta de "I-Juca-Pirama" e "Canção do Tamoio". E o poema se organiza por oposição sempre de dois elementos: oprimido / opressor; colonizado / colonizador; índio / branco; selvagem / civilizado. Este binarismo, marca registrada não só da escritura romântica como, mais ainda, dos seus textos de intervenção social, bem se encaixa no formato por vezes panfletário do poema nisiano. Vejamos o poema:

Lá, quando no Ocidente o sol havia Seus raios mergulhado, e a noite triste Denso-ebânico véu já começava Vagarosa a estender por sobre a terra; Pelas margens do fresco Beberibe, Em seus mais melancólicos lugares, 
Azados para a dor de quem se apraz Sobre a dor meditar que a Pátria enluta! Vagava solitário um vulto de homem, De quando em quando ao céu levando os olhos, Sobre a terra depois triste os volvendo... (p. 35)

O personagem surge no poema sozinho, ao anoitecer, às margens do Beberibe, marcado pelo sofrimento e como alguém que, apesar disso ou por isso mesmo, medita sobre a dor que enluta sua pátria. É preciso observar que não se trata de um silvícola ou um selvagem, mas de um vulto de homem. Após lembrar seu passado de lutas, o extermínio de seu povo e a família morta, ele amaldiçoa o invasor ("fero luso ambicioso") e também outros índios (como os Tabajaras, "raça escrava") que se aliaram aos portugueses.

No poema, a vingança dos Caetés se consuma na morte solitária de Camarão, na submissão portuguesa à coroa espanhola, na traição de Calabar, na independência do Brasil. Mas o índio ainda tem mais desejos de vingança. Clama então ao "Gênio do Brasil" para que volte e restitua a dignidade aos seus filhos. Ouve-se o fogo da artilharia e o grito brasileiro de "Avante! Libertemos a terra dos Caetés!”. É a Revolução Praieira com Nunes Machado à frente. O Caeté desloca-se para o campo da batalha - na Soledade - no momento em que Nunes Machado tombava. A poetisa lamenta sua morte, ressalta a importância deste herói para o povo pernambucano, faz graves acusações ao governador da província e termina com uma profissão de fé no futuro. O "Gênio do Brasil" surge e tenta consolar o índio, para que não lamente a perda do amigo: "Não chores, ó Caeté, o amigo teu". Os argumentos são muitos. Lembra-lhe que o brado e a inspiração que Nunes Machado seguiu foram dele, "Gênio do Brasil”. Lembra ainda que um herói não morre para a Pátria. Referindo-se a alguns revolucionários da Confederação do Equador e das revoluções de 1817 e de 1824, os quais depois se esqueceram dos ideais de liberdade e se uniram ao opressor, destaca o papel de Nunes Machado, que, ao contrário daqueles, preferiu a morte a abandonar seus irmãos. O Caeté vai para as matas do Catucá, nos arredores de Recife, à procura de um povo que o ajude em sua 
vingança. Como não encontra tal auxílio, resolve partir só: bastamlhe seu braço e suas flechas, convicto de que, vingando o líder liberal, estaria vingando também sua extinta raça. Ao voltar para a cidade, surge um vulto de mulher na sua frente, tão feio e descarnado que chega a assustá-lo.

Pára, miserando, disse ela ao Caeté,

Os restos depõe de tanta bravura,

Encara-me atento... perderás a fé

Com que praticar vais uma loucura! (p. 52)

Tal personagem é a "Realidade" que procura dissuadi-lo do gesto inútil e o manda voltar às selvas. Neste momento surge outra figura antropomorfizada: a "mais bela virgem", que olha com tristeza para a cidade. É a "Liberdade" que se afasta, uma vez que as tropas liberais foram sufocadas e morreu "seu grande Amador". Enquanto o Caeté está envolvido por esta visão, sai da cidade um "monstro enroscado", "feroz", qual "enorme serpente", acompanhado das "Fúrias", que se dirigem ameaçadores em direção à Virgem. Tal figura de tom místico é o "Despotismo" e as "Fúrias", seu braço armado. O Caeté quer defender a Liberdade mas, novamente, a Realidade chama-o à razão. Garante-lhe que a Virgem arrebanhará um exército de defensores e voltará para expulsar o monstro que agora domina o Recife. Ele, o Caeté, deve ouvi-la e voltar às selvas, onde somente lá será livre. É o que ele faz. Nas últimas estrofes o herói encontra-se às margens do Rio Goiana, expandindo sua dor, chorando a morte dos seus e de Nunes Machado.

Aí está, em poucas palavras, o enredo do poema de Nísia Floresta. O trajeto poético do índio Caeté perpassa a história pernambucana - da colonização ao Império - ao mesmo tempo em que se refere a alguns pontos geográficos do Estado de Pernambuco. Inicia seu percurso nas margens do Beberibe, depois vai à Saudade bairro em que se situava o Quartel da Soledade - e termina nas margens do Goiana, rio que banha uma cidade do mesmo nome, no interior do Estado. Este trajeto inclui também uma revisão de vários momentos de conflito da história pernambucana, até deter-se na revolução de 1848, 
enquanto realiza uma verdadeira retrospectiva da dominação estrangeira no contexto nordestino, com seus heróis e traidores.

Desde o início do poema, o índio apresenta-se consciente de sua condição de derrotado. À medida que percorre lugares e tempos, sua dor inicial transmuda-se, primeiro, em desespero e, depois, em desilusão com a própria sorte. Mas nem por isso ele assume uma postura acomodada e deixa de lutar. Sua desilusão advém do nível de consciência que adquiriu ao defrontar-se com a repressão. De certo modo, é, esta, a responsável por sua sobrevivência.

A sexta e a sétima estrofes, em breve digressão, opõem o índio livre do passado ao herói vencido do presente:

Era da natureza o filho altivo,

Tão simples como ela, nela achando

Toda a sua riqueza, o seu bem todo...

O bravo, o destemido, o grão selvagem,

O Brasileiro era... um Caeté! (p.36-7)

Estes versos e alguns outros contêm os principais traços divulgados no rousseaunismo. Sem dúvida é a imagem do bon sauvage que parece estar aí descrita. Também o mito da "terra que tudo dá" - preconizado três séculos antes por Caminha - surge no poema e, se não fosse o pretérito verbal utilizado no primeiro verso "Era da natureza..." - poder-se-ia até pensar que esta fosse a situação do índio no momento presente do texto. Mas não. Trata-se mesmo de um tempo passado e perdido para o indígena.

E enquanto relembra os "bons tempos", o poema introduz a dominação estrangeira e subseqüente rompimento da harmonia. As recomendações de Ferdinand Denis acerca da sensibilidade do autor para os "erros do passado" e os lamentos pelas nações exterminadas parecem ecoar nos versos dessa autora:

Aqui, mais tarde trazendo

$\mathrm{Na}$ alma triste, acerba dor,

Vim chorar as praias minhas

Na posse de usurpador! 
Que de invadi-las

Não satisfeito,

Vinha nas matas

Ferir-me o peito!

Ferros nos trouxe,

Fogo, trovões,

E de cristãos

Os corações

E sobre nós

Tudo lançou!

De nossa terra

Nos despojou!

Tudo roubou-nos,

Esse tirano,

Que povo diz-se

Livre e humano! (p. 37)

A lusofobia outro traço do movimento romântico - surge nestes versos e em outros com virulência tanto na fala do personagem, como na da poetisa. A catequese - desculpa maior dos portugueses na prática da dominação - é lembrada com ferina ironia:

Ao jugo de tiranos opressores,

Que em nome do piedoso céu vieram

Tirar-nos esses bens que o céu nos dera!

As esposas, a filha, a paz roubar-nos!...

Trazendo d'além-mar as leis, os vícios,

Nossas leis e costumes postergaram!

(...)

Maldito, ó maldito sejas,

Renegado Tapeirá!

Teu nome em nossas florestas

Em horror sempre será! (p. 38)

Não cabem, pois, no quadro de caracterização deste índio, os epítetos de "inocente", de "puro" e de "bondade natural", idealizados nas teorias filosóficas européias. O contato com o homem branco revelou-se pernicioso demais para ele e - a história nos mostra com conseqüências irreversíveis. A dor e a revolta do indígena vêm 
precisamente da consciência dessa irreversibilidade e do meio-lugar (ou lugar nenhum) em que se encontra. O discurso da narradora absolutamente preso ao do índio, e às vezes até se confundindo com o dele, acrescenta um dado fundamental: o da perda da identidade, por parte do silvícola.

Indígenas do Brasil, o que sois vós?

Selvagens? os seus bens já não gozais...

Civilizados? não... vossos tiranos

Cuidosos vos conservam bem distantes

Dessas armas com que ferido tem-vos.

De sua ilustração, pobres caboclos!

Nenhum grau possuís! ... Perdestes tudo,

Exceto de covarde o nome infame... (p. 39)

Pode-se notar aqui o tom de libelo anticolonialista que impregna o texto. Em lugar de o escritor branco que idealiza a figura do índio passando por cima de sua verdadeira situação, temos um discurso denunciador da opressão. Em contato com o estrangeiroinvasor, ele deixa de ser índio, sem conseguir tornar-se igual ao branco. Nem índio mais, nem nunca um branco: apenas um marginalizado caboclo, sem terras, sem consciência, sem ilustração.

A preocupação com o índio pós-civilização já havia aparecido no poema "Três dias de um noivado", de Teixeira e Sousa, que trata justamente das conseqüências sociais do confronto de raças. Os protagonistas eram uma mestiça (Mury’ba) e um Guarani civilizado (Corimbaba) que não se reconhecem mais enquanto índios, nem se identificam com os brancos. Mais tarde, Gonçalves Dias tematiza este não-lugar em "Marabá" e, em outra ocasião, respondendo às críticas do jornal $A$ Religião, afirma:

...o índio no estado de catequese seria como um ente de transição, passando, sem preparatório, instantaneamente de um para outro estado, tornara-se igualmente incapaz de ambos - de viver nas cidades com os homens que chamamos civilizados ou de viver nas selvas entre os que chamamos bárbaros. ${ }^{?}$

${ }^{9}$ Apud MATOS, 1988. p. 41. 
Mas apesar do conhecimento que revela acerca da difícil situação dos indígenas, Gonçalves Dias nem sempre se preocupou em representá-la na sua obra. Pelo contrário, compôs também um "Canto do Índio" que nega frontalmente as colocações mais contundentes e indignadas diante deste triste quadro de repressão e etnocídio.

Consciente ou inconscientemente, os escritores faziam, pois, suas opções, que podem se resumir em duas: reconhecer o índio como portador de identidade própria, ou "criar-lhe" uma à sua maneira. Nísia Floresta adota a primeira opção, assim como talvez Teixeira e Sousa no poema anteriormente citado. A autora não só reconhecia, como denunciava o esvaziamento da personalidade cultural do índio mediante o contato com o colonizador. Seu personagem não adota valores estrangeiros, mas mantém a duras penas sua identidade. E a consciência do Caeté revela-se através do ódio que explode (este, em ambas as falas, tanto na do índio quanto na da narradora aí implícita) nas acusações que dirige aos traidores e em supostas vinganças que alimenta.

A vingança, elemento intrínseco à cultura do índio, longe de ser dissimulada está presente em quase toda a extensão do poema. Afinal, era o espírito de vingança que levava uma tribo a guerrear com outra, às vezes durante dezenas de anos. Esse sentimento, apesar de sua evidência, foi negado por muitos dos cronistas que aqui estiveram ou pelos filósofos que se basearam em relatos de viagem, simplesmente porque não combinava com a imagem idealizada do homem natural, feliz e bondoso. Montaigne, por exemplo, numa tentativa extrema de preservar o mito do bom selvagem, chegou a afirmar que os índios guerreavam "por uma espécie de emulação na prática da virtude". ${ }^{10}$

E não foram poucos os escritores que assim procederam, negando aos seus personagens qualquer reação mais agressiva ou pouco condizente com o ideal que preconizavam. Daí muitos

${ }^{10}$ FRANCO, 1976. p. 151. 
focalizarem preferencialmente o índio pré-cabralino com suas virtudes intactas, vivendo ainda numa "Idade de Ouro", distante do contato com o invasor. Não deixava de ser - naturalmente - uma forma de escamotear o problema do índio que nesta época também sofria violentamente a perda de suas terras, o abuso de suas mulheres pelos brancos, o extermínio em massa de tribos, tanto pelas armas, como pela catequese.

Mas parece não ter sido essa a intenção de nossa autora. Longe de mitificar seu personagem, ela o constrói a partir de dados concretos retirados da realidade brasileira. Tanto é assim que seu herói é um índio vencido. Desde o início, vencido. Enquanto nos outros escritos encontra-se mais freqüentemente a imagem do índio que luta ("bravo e forte") e que por vezes vence, em Nísia temos o índio já derrotado e, o que é mais importante, consciente de sua derrota. Por isso, de protagonista da história brasileira ele passa neste poema a mero espectador, uma vez que se encontra à margem do processo histórico, restando-lhe apenas observar as novas lutas que surgem. Sintomaticamente, tanto no início como no final do poema, o índio encontra-se à beira de um rio. Através desta localização do personagem, a autora reforça o estatuto de marginalização social e a derrota do silvícola no processo histórico.

No segundo momento do poema, alarga-se sua perspectiva histórica e o território episódico do texto também se amplia, ocorrendo não só a "presentificação" do drama do indígena como a sua identificação com o drama vivido pelos liberais pernambucanos. O índio permanece em cena e, de certa forma, fornece o pretexto para a introdução da Revolta Praieira. A partir do grito de ataque dos revoltosos, efetua-se a correspondência com os episódios apresentados na primeira parte do poema: "Eia! avante! guerreiros, libertemos/ A terra dos Caetés, a terra nossa!"

Os revolucionários são os novos guerreiros e a terra pernambucana é a mesma dos Caetés, numa alusão evidente ao grupo indígena que desde o período pré-cabralino habitava o litoral dos atuais Estados de Pernambuco e Alagoas. Um guerreiro - Nunes 
Machado - se destaca, apresentado como um "descendente" dos "bravos Caetés", cuja "triste raça jurou de vingar". E pode-se concluir que, da mesma forma que os pernambucanos de hoje descendem dos Caetés que ali habitavam, os opressores de hoje correspondem também aos que trezentos anos antes invadiam aquelas terras. Os opressores de agora mantêm uma estreita identificação ideológica com o colonizador branco, porque descendem da mesma elite donatária que recebeu de presente as terras.

Coerentemente, se no primeiro momento a fala da narradora se confundia com a do índio, agora esta identificação se faz com a fala dos revoltosos de forma total e apaixonada, tomando partido dos brasileiros "ofendidos e explorados" em qualquer etapa da sua história. Nunes Machado, alçado à categoria de herói nacional, ganha aí atributos de um verdadeiro herói índio, tal a sua coragem e valor:
À frente se arremessa da batalha, Impávido ao inimigo o peito mostra, Esquecendo, ai da Pátria! que era homem, Livre pernambucano, a quem as balas De perfídios inimigos mais buscavam! (p. 46)

Na descrição do Caeté havíamos encontrado entre seus vários atributos, o da coragem de "ir de peito aberto" às guerras não escondendo armas tal como faziam os inimigos brancos. Nunes Machado também assim se comporta, confundindo-se quase com o guerreiro de quem se dizia descendente. O Caeté agora presencia o desfecho de uma luta que é e não é sua: é sua, porque a luta se trava em suas terras; e não é sua, porque são outros os ideais aí em jogo, o que só compreenderá mais tarde. Ao ver o herói morto, "Transido de dor o triste Caeté/ Suspira, lamenta, chora, se exaspera..."

Testemunha da história, o índio é identificado com o líder que tombou, como se esta derrota fosse mais uma derrota de seu povo. Também a voz acusadora propõe outras possíveis identificações, expondo-se a sérios riscos. As denúncias, extensas e violentas, dirigidas ao governador da Província, por exemplo, responsabilizado pelo massacre e profanação do cadáver de Nunes, revelam coragem 
em acusar autoridades que, no momento, recebiam elogios e prêmios do Imperador. A voz que denuncia parece não temer represálias da parte dos governantes.

É dramática a situação do índio e do revolucionário, ambos derrotados por seus opressores. Esta derrota não deixa de ser também a derrota de todo o povo pernambucano, tão orgulhoso de sua tradição de luta em movimentos nativistas. Por isso, o pranto em todo o poema e a lágrima do Caeté. O Gênio do Brasil, personificação do espírito de brasilidade, consola o índio lembrando a coragem e o heroísmo de Nunes:

Não chores, ó Caeté, o amigo teu:

Que caiu, não morreu, porque o bravo

Constante defensor da Pátria sua,

Para a Pátria não morre. (p. 49)

Mas o índio - como índio que é - tem desejos de vingança. E neste momento instala-se o conflito: permanecer índio ou adotar os ideais liberais? Este conflito é magistralmente resolvido no texto através da antropomorfização de duas personagens (sempre o binarismo), em tudo opostas. Inicialmente surge um "vulto de mulher" "descarnado" e de "triste cor era seu rosto afeado", que chega a assustá-lo. Esta, parece-me, foi também uma forma encontrada pela poetisa para desmitificar a figura do guerreiro "bravo e invencível", imagem esta que estava se criando em torno do índio brasileiro.

O bravo selvagem atônito ficou...

- Quem és; lhe pergunta, infernal deidade?

- Uma tal visão de inferno não sou:

Sou cá deste mundo, a Realidade. (p. 52)

O tom realista, perceptível na descrição da figura "triste" e "descarnada", se impõe. A personificação da Realidade- ou a voz da razão - é quem pronuncia as palavras sensatas que ele traz dentro de si, a partir mesmo da consciência que conserva de sua situação de oprimido na própria terra. É a consciência do real que o texto configura em uma outra personagem: 
Volta às selvas tuas, vai lá procurar

Alguns desses bens, que aqui te hão tirado:

Não creias, ó mísero, jamais encontrar

A paz, a ventura que aqui tens gozado. (p. 52)

Em contraposição a esta figura de mulher feia, surge uma outra visão também feminina, nos ares, acompanhada de "celestes acordes, vozes sonorosas". O tom agora é outro, idealizante, bem diverso do que foi há pouco utilizado para introduzir a Realidade. "Em nuvens douradas vem do firmamento/ A mais bela virgem num trono de rosas!"

Esta figura representa o outro lado do seu conflito. A "virgem" de "feições risonhas", "olhar cintilante", "ar varonil" e "porte majestoso" é a personificação da Liberdade, que sai da cidade do Recife, expulsa pelo Despotismo (um "monstro enroscado") e pelas Fúrias, seu braço armado. O uso de elementos mitológicos - Fúrias e Virgem - visa representar o conflito interior do personagem entre a realidade e a fantasia. Isto é: entre manter-se índio e enfrentar a realidade tal como ela se apresentava para ele, ou refugiar-se numa fantasia e abraçar a causa dos revolucionários liberais.

Um movimento fez de impaciência

Da natureza o filho.

Seus braços estendendo à bela Virgem,

Quis ir a seu socorro...

Mas os olhos volvendo à terra vê

Realidade horrível!

- Dissipa as ilusões, filho dos bosques

A meu rosto te afaze;

E verás, que tão feia eu não serei,

Como agora pareço,

Se de ilusões a mísera humanidade

Não amasse nutrir-se,

Horrenda a face minha não seria

A seus olhos depois... (p. 53-4)

O dilema do Caeté configura, portanto, uma opção obrigatória a nível da narrativa: o personagem deve atender à demanda 
escapista e sonhadora do Romantismo ou manter-se preso às condições reais de vida do indígena da época? Dedica sua vida a uma visão de liberdade - muito bem colocada no alto como uma virgem branca, inacessível para ele - ou põe os pés na terra e ouve a voz da razão que à primeira vista lhe pareceu tão repulsiva?

Trata-se aí de um posicionamento ideológico bem claro da narradora. Entre defender ideais e sobreviver, cabe ao oprimido decidir pela sobrevivência. Ao invés de dar aos leitores mais um índio composto a partir da imagem de selvagem que o europeu idealizava, temos o silvícola brasileiro que sofre a consciência da extinção de seu povo e que percebe a necessidade de se afastar da cidade como condição mesmo de autopreservação. Muito distante, portanto, do Peri alencarino conformado em sua submissão, ou do guerreiro gonçalvino em sua bravura idealizada.

A lucidez que a autora demonstra em relação aos problemas de seu tempo funciona como uma das condições que favorecem o seu profundo envolvimento neste texto com as causas do índio e dos liberais, ao mesmo tempo em que impede a adoção de posturas do Romantismo idealizante. O índio criado por Nísia Floresta aparece fundamentalmente construído a partir de sua condição de derrotado e sabendo bem que os brasileiros de então nada fariam por ele e seu povo, pois lutam por novos ideais e "são outros seus planos, outra sua crença”. A República, provavelmente. Não há esperança ali na cidade, é o que diz o texto.

Este grande povo, que o nome tomou

De um pau simulando das brasas a cor,

Nascido na terra, que Deus lhe outorgou,

De seu bem só cura, não de tua dor.

Em campo ei-lo agora com as armas na mão

Mas seja um partido, ou outro que vença,

A tua ventura não creias farão!

São outros seus planos, outra a sua crença. (p. 52-3)

O final é melancólico, como já foi o início. O pranto de Caeté confunde-se agora com as águas do Goiana, berço de Nunes 
Machado e palco da adolescência de Nísia Floresta. Não há motivos para alegria, pois o índio está só, saudoso de seu povo e da vida que teve um dia. Não há esperança para ele, é o que nos diz o tom de amarga elegia dos últimos versos. Cabem aqui as palavras, sem dúvida pertinentes, de Wilson Martins, quando considera A lágrima de um Caeté o "epitáfio poético" da Revolução Praieira. Acrescentaria a esta afirmação que, na verdade, se trata de um duplo epitáfio, já que pranteia igualmente o fim da resistência indígena frente ao branco invasor.

\section{Do indianismo ao indigenismo precursor}

Tendo em vista o que foi exposto acerca do poema e, principalmente, das diferenças existentes entre este poema e alguns textos da mesma época no que diz respeito à abordagem da problemática do índio, pergunto: seria o caso de se considerar esta lágrima nisiana apenas mais um poema indianista? Até que ponto não haveria aí uma ruptura para com a idealização do selvagem, segundo os padrões do romantismo europeu?

O estudo crítico que Maria José de Queiroz ${ }^{11}$ realizou do indianismo hispano-americano abriu novas perspectivas para o enfoque da questão. Neste trabalho a autora estabelece uma interessante distinção entre "indianismo" e "indigenismo". O primeiro termo - indianismo - configuraria a abordagem literária nossa conhecida, baseada no mito do bom selvagem, que "pondera no índio a beleza, a força, o heroísmo", e se detém "sobretudo, em exterioridades". ${ }^{12}$ Já o segundo termo - indigenismo - referir-se-ia a uma "corrente muito mais legítima e concreta", pois "foge às considerações estéticas, ao exotismo, ao espetáculo. Indaga pelo homem. Nem mito, nem símbolo, nem herói. Criatura triste e

${ }^{11}$ QUEIROZ, 1962.

${ }^{12}$ QUEIROZ, 1962. 
miserável, espoliada e explorada pelos brancos, esquecida pela civilização". Enfim, pretende tratar "o índio, como ele $\hat{e}$ '. ${ }^{13}$ A primeira perspectiva implica um afastamento da realidade através da idealização do índio; a segunda, pelo contrário, se esforça por se aproximar da sua realidade mais triste, de derrotas.

Em última instância, a tendência indigenista termina por se identificar com o pendor realista de crítica social e histórica, já presente no seio do Romantismo. Ao se voltar para a problemática políticosocial, a literatura refletia os ideais democráticos herdados do Iluminismo. Expressava também os anseios nacionalistas ligados à defesa do índio e às lutas abolicionistas, neste momento histórico de emancipação que a nação atravessava. Daí a atribuição da "missão civilizadora" de que o escritor se investia.

No meu entendimento, A lágrima de um Caeté aproxima-se bem mais desta segunda perspectiva que da tradicional, pois dá voz ao índio e defende seu direito de lutar pela liberdade contra o colonialismo estrangeiro. Denuncia ainda o despotismo português através da invasão de terras e do extermínio das raças nativas. A simpatia da autora pelo oprimido evidencia-se neste texto ao se mostrar sensível ao sofrimento do Caeté e tudo observar a partir desta ótica. Por estas razões considero este texto uma nova página da temática indígena do nosso romantismo: mais que um poema "indianista" temos aí talvez uma das primeiras abordagens de cunho indigenista de nossa literatura. A defesa intransigente do ponto de vista do vencido e do oprimido, as denúncias reiteradas da espoliação que os índios sofriam são marcas textuais que possibilitam considerar este poema como um protesto pela estereotipia que se fazia do indígena. E esse protesto terminará por revelar as contradições existentes entre o pensamento dominante e a realidade histórica. Tratava-se, pois, do futuro daquele mesmo homem "inocente", "bondoso" e inspirador de tantas filosofias.

13 QUEIROZ, 1962, 22. 
Se o poema denuncia a situação real de vida do indígena e trata da derrota liberal dos praieiros, ele está, por conseguinte, se afastando do exotismo romântico e se aproximando de uma concepção realista fundada na crítica social. Desta forma, a construção indigenista pode mesmo ser considerada como uma dramatização do herói dividido, deslocado, sem lugar.

Assim, em vez de uma extensa obra indianista, Nísia nos deixou um único poema, este A lágrima de um Caeté. Mas neste único poema a autora inova, atualizando e problematizando a questão do índio, mediante a construção de uma seqüência analógica, em que a relação entre oprimidos e opressores de ontem se equivale à de sua época. Seu herói índio não corresponde ao ideal preconizado pelas filosofias européias que influenciaram tantos escritores românticos de seu tempo, tais como Alencar, Gonçalves de Magalhães e mesmo Gonçalves Dias. Ao contrário, configura-se quase num "anti-bon-sauvage": não é inocente e puro, sofreu a maldade e a violência do branco e guarda ainda profundos desejos de vingança. O grande mérito do poema pode, talvez, residir na aguda consciência que este personagem apresenta em sua trajetória poética (uma quase via-crucis) ao encontro de sua verdade. Longe de realizar aí apenas a utilização de um tema da moda, ${ }^{14}$ o texto recria o real na medida em que constrói seu repertório buscando na história passada e na presente, fatos e personagens verídicos.

Enquanto muitos escritores da época dissimulavam os conflitos advindos da colonização e da aproximação branco/índio, Nísia acentua essas diferenças e preconiza a impossibilidade de sua convivência. Enquanto aqueles se negavam a tratar das questões políticas e sociais de seu tempo, Nísia toca fundo a problemática da

${ }^{14}$ Em 1849, entre os poucos textos indianistas publicados, estavam A metamorfose
original: Moema e Camorogi, de Ladislau dos Santos Titara (1835), "Nênia", de
Firmino Rodrigues Silva (1844), "Os três dias de um noivado" de Teixeira e Sousa
(1844) e os dois livros de Gonçalves Dias: Primeiros cantos (1847) e Segundos
cantos (1848). A partir desta data, sim, surgem dezenas de publicações indianistas. 
opressão e arrisca-se, por isso mesmo, a sofrer as conseqüências nefastas da censura.

Volto assim à questão colocada no início desta reflexão: o que seria mais importante, o índio enquanto nação explorada ou como elemento exótico de ornamento? Quanto ao aproveitamento literário do tema, é preciso concordar que a primeira opção contribui enquanto peça de intervenção política e social. Além de denunciar o extermínio dos povos indígenas, a autora funde, neste mesmo texto, ao relato da história da derrota indígena, o relato poético da história pernambucana na busca frustrada da independência e da liberdade.

Apesar da pouca receptividade crítica deste poema, citado por Adauto da Câmara e Modesto de Abreu como texto menor ou pouco expressivo da obra nisiana, as duas ou três edições do poema no mesmo ano nos permitem acreditar que ele obteve em sua época uma relativa repercussão entre o público-leitor, notadamente entre os liberais, que aí estavam marcadamente atuantes e representados. De fato, o poema não apresenta uma elaboração refinada do material. Mas se lembrarmos as circunstâncias de sua realização e os propósitos de intervir no grave momento histórico, veremos que o que de fato importava para a autora não eram as glórias advindas de uma bem cuidada elaboração estética, mas sim contribuir de alguma forma na concretização do sonho democrático. A lágrima de um Caeté padece, pois, do dilema que afeta a literatura política como um todo: entre a ideologia e a estética, o fazer e o refazer em busca da bela página, impõe o texto empenhado e construído no calor da hora.

O que não se deve esquecer é que era preciso muita coragem para dizer tudo que aí está. E o pseudônimo que utilizou na ocasião Telesila - mais que ocultar revela-nos a intenção da escritora de resistir sempre e enfrentar as dificuldades, tal como a poetisa e heroína de quem tomou de empréstimo o nome. ${ }^{15}$ Como Telesila,

\footnotetext{
15 Telesila nasceu em Argos no ano de VI a.C.. Ficou célebre pela resistência que impôs ao rei de Esparta, Cleómenes, quando este quis invadir sua cidade. Como os homens estavam fora, ela armou os escravos e as mulheres que, juntos, evitaram a invasão e expulsaram o exército de Cleómenes.
} 
Nísia foi uma guerreira que lutou, neste poema, contra a opressão do índio pelo colonizador, pela liberdade dos povos oprimidos. Sempre determinada, enfrentou também outras lutas, como podese ver nos demais livros que escreveu, e que aos poucos retornam às mãos dos leitores.

\section{Referências Bibliográficas}

CÂMARA, Adauto. A Lágrima de um Caeté. Revista das Academias de Letras. Rio de Janeiro, 1938.

CÉSAR, Guilhermino. Historiadores e críticos do Romantismo. Vol. I. Rio de Janeiro: Livros Técnicos e Científicos. São Paulo: Editora da USP, 1978.

FRANCO, Afonso Arinos de Melo. O índio brasileiro e a Revolução Francesa. 2 ed. Rio de Janeiro: José Olympio; Brasília: INL, 1976. MARCUCCI, Ettore. (Trad.) Le lagrime d'un Caeté, de Nísia Floresta. Florença, 1860.

MARTINS, Wilson. História da inteligência brasileira (1794-1855). Vol. II. São Paulo: Cultrix, Editora da USP, 1977.

QUEIROZ, Maria José de. Do indianismo ao indigenismo nas letras bispano-americanas. Tese apresentada à Faculdade de Filosofia da UFMG, para a Cátedra de Literatura Hispano-americana. Belo Horizonte, 1962.

QUINTAS, Amaro. O sentido social da Revolução Praieira. 6 ed. Recife: Massangana, Fundação Joaquim Nabuco, 1982. 


\section{Resumo}

Entre os diversos livros que Nísia Floresta (1810-1885) publicou, um se destaca por se inserir de forma especial no contexto romântico indianista brasileiro. Trata-se do poema A lágrima de um Caeté, publicado no Rio de Janeiro em 1849, que obteve ampla repercussão em seu tempo, por conciliar dois dramas: o do índio brasileiro espoliado pelo colonizador, e o dos liberais, que acabavam de sofrer mais uma derrota na Revolução Praieira, em Pernambuco. O poema se inscreve de forma tão original entre os escritos indianistas do período, que nos permite, inclusive, considerá-lo um legítimo representante do indigenismo precursor de nossas letras.

\section{Abstract}

Nísia Floresta (1810/1885) has published, among many other books, one that outstands, because it fits, in a special way, within the Brazilian Indian romantic context. It is the poem named "A Lágrima do Caeté" (A Tear from a Caeté), issued in Rio de Janeiro, 1849. It caused as enormous impression at its time. It united two dramas: the Brazilian Indian, plundered by the colonizer and the liberals, who had just been defeated again in the "Revolução Praieira" (State of Pernambuco). That poem is presented in such an original manner, among others written pieces concerning the so-called Indian Literature of the period, that allows us to consider it as a genuine representative of the former themes inspired by Brazilian Indians life. 